\title{
Internal jugular vein thrombosis presenting as paraneoplastic syndrome in benign cystic teratoma of ovary: a case report
}

\section{Vidhya Ramalingam, Lakshminarasimhan Srinivasan*, Madurai Padmanabhan Kanchana}

Department of Medical Oncology, Institute of Obstetrics and Gynaecology, Madras Medical College, Chennai-8, Tamil Nadu, India

Received: 26 October 2016

Accepted: 28 November 2016

\section{*Correspondence:}

Dr. Lakshminarasimhan Srinivasan,

E-mail: drnarasimhan@rediffmail.com

Copyright: () the author(s), publisher and licensee Medip Academy. This is an open-access article distributed under the terms of the Creative Commons Attribution Non-Commercial License, which permits unrestricted non-commercial use, distribution, and reproduction in any medium, provided the original work is properly cited.

\begin{abstract}
Internal jugular vein thrombosis is a rare vascular disease that can be overlooked or misdiagnosed and is generally seen in persons with intravenous drug abuse or in patients with prolonged central venous catheterization due to iatrogenic trauma. The most common germ cell tumour of the ovary is benign (mature) cystic teratoma, occurring in adolescents and young women. We are presenting a case of a 50-year-old premenopausal woman, diagnosed to have right internal jugular vein thrombosis extending into the right subclavian and axillary vein. Her laboratory investigations revealed no predisposing cause of thrombosis. Four months later she was evaluated for menorrhagia and imaging studies showed multiple uterine fibroids with left ovarian mass (ovarian teratoma) with moderate ascites and her tumour markers levels of CA125 was elevated. She underwent staging laparotomy, total abdominal hysterectomy with bilateral salpingo-oophorectomy and pelvic lymph node dissection with infracolic omentectomy. Pathologically, ovarian cyst showed mature thyroid tissue with islands of bone, muscle tissue and fatty tissue consistent with benign cystic teratoma. Postoperatively her tumour marker CA125 level returned to normal levels and there was no reaccumulation of fluid. As there were no predisposing factors for internal jugular vein thrombosis, it was concluded to be a paraneoplastic syndrome preceding the diagnosis of benign cystic teratoma. To the best of our knowledge this is the first case report in the literature with an association between internal jugular vein thrombosis and benign cystic teratoma with raised serum tumour marker CA 125.
\end{abstract}

Keywords: Benign cystic teratoma ovary, Internal jugular vein thrombosis, Paraneoplastic syndrome

\section{INTRODUCTION}

The venous thrombosis of neck and the upper limbs is very rare as compared to the incidence in lower extremities. Internal jugular vein thrombosis can give rise to pulmonary embolism, septic emboli, generalized septicaemia and can even extend intra cranially causing cerebral oedema. Patients commonly present with painful swelling in the neck although sometimes patients may be asymptomatic. ${ }^{1}$

The most common germ cell tumour of the ovary is benign cystic teratoma occurring in adolescents and young women. ${ }^{2}$ It represents $10-25 \%$ of all ovarian neoplasms \& $60 \%$ among benign ovarian neoplasms. ${ }^{3}$ Twenty percent of patients can have complications including torsion, infection and malignant transformation. ${ }^{4}$ Benign cystic teratoma arises from one or more of the well differentiated tissues of germ cell layers (ectoderm, endoderm and/or mesoderm) leading to heterogeneous composition of tissues responsible for occasional elevation of various tumour markers like carbohydrate antigen $19-9$ and $125 .^{5}$ The combination of basic laboratory and imaging findings can aid in the diagnosis of benign cystic teratoma of ovary and its complications. The serum tumour markers can provide additional information regarding the presentation and the complications of the disease. ${ }^{6}$ 


\section{CASE REPORT}

A 50-year-old premenopausal woman with regular menstrual cycles, G4P4, presented with right upper limb swelling of one week duration. Physical examination revealed diffuse oedema involving entire right upper limb. There was no palpable swelling in the neck or right axilla. Ultrasound with Doppler study showed right internal jugular vein thrombosis. Contrast enhanced CT scan of Neck showed a large thrombus, extending from the right internal jugular vein up to superior vena cava. The thrombus was also seen extending into the right subclavian and axillary vein. The right internal jugular vein was dilated and showed peripheral contrast opacification.

The blood investigations showed normal white blood cell, red blood cell and platelet count. The peripheral smear was reported normal. The laboratory investigations done to determine the cause of thrombosis revealed no abnormalities as shown in Table 1 .

The patient was started on low molecular weight heparin $7.5 \mathrm{mg} \mathrm{S} / \mathrm{C}$ once daily. Oral anticoagulant warfarin was started with maintenance of international normalized ratio (INR) within the therapeutic range (2-3). Her right upper limb swelling gradually subsided within 2 weeks of treatment.

Four months later she presented with menorrhagia of one week duration. Ultrasound of abdomen showed moderate ascites and enlarged uterus with fibroids. Contrast enhanced CT scan of whole abdomen showed multiple uterine fibroids with left ovarian mass (ovarian teratoma) with moderate ascites.

Ascitic fluid analysis was negative for malignant cells. Ascitic fluid culture and sensitivity revealed no growth and the smears for mycobacterium tuberculosis were negative. Ascitic fluid adenosine deaminase (ADA) value was 3.1U/L (normal 0-30U/L). She underwent endometrial curettage which showed secretory endometrium and chronic inflammation of endocervical tissue. Her serum tumour marker CA 125 level was raised. The serum tumour marker levels are as shown in Table 2.
Epithelial ovarian tumour marker is raised while germ cell tumour markers are within normal range.

She underwent staging laparotomy, total abdominal hysterectomy with bilateral salpingo-oophorectomy and pelvic lymph node dissection with infracolic omentectomy. Per operative findings were, a left ovarian mass of $8 \times 6 \mathrm{~cm}$ with irregular surface, variable consistency, adherent to omentum. Fifty millilitres of ascitic fluid was aspirated. Pathologically, ovarian cyst showed mature thyroid tissue with islands of bone, muscle tissue and fatty tissue consistent with Benign (mature) cystic teratoma. All the lymph nodes and omentum were negative for malignancy. Ascitic fluid was negative for malignant cells.

Postoperatively her serum tumour marker CA125 level returned to normal level. There was no reaccumulation of fluid. She continues to be on follow up in medical oncology as the ovarian tumour is benign (mature) cystic teratoma.

Table 1: The laboratory investigations values.

\begin{tabular}{|c|c|c|}
\hline Laboratory test & Value & $\begin{array}{l}\text { Reference } \\
\text { interval }\end{array}$ \\
\hline Homocysteine & $\begin{array}{l}10.93 \\
\mathrm{umol} / \mathrm{L}\end{array}$ & 4.44-13.56 umol/L \\
\hline $\begin{array}{l}\text { Cardiolipin AB } \\
\text { IgG }\end{array}$ & $\begin{array}{l}2.07 \\
\mathrm{GPL} / \mathrm{ml}\end{array}$ & $\begin{array}{l}<12 \mathrm{GPL} / \mathrm{ml} \text { is } \\
\text { negative and }>18 \\
\mathrm{GPL} / \mathrm{ml} \text { is positive }\end{array}$ \\
\hline $\begin{array}{l}\text { Cardiolipin AB } \\
\text { IgM }\end{array}$ & $\begin{array}{l}1.24 \\
\mathrm{MPL} / \mathrm{ml}\end{array}$ & $\begin{array}{l}<12 \mathrm{MPL} / \mathrm{ml} \text { is } \\
\text { negative and }>18 \\
\mathrm{MPL} / \mathrm{ml} \text { is positive }\end{array}$ \\
\hline $\begin{array}{l}\text { Prothrombin } \\
\text { time (PT) } \\
\text { Control }\end{array}$ & $\begin{array}{l}13.5 \\
\text { seconds }\end{array}$ & 11.5-14.5 seconds \\
\hline Control & $\begin{array}{l}13.0 \\
\text { seconds }\end{array}$ & \\
\hline INR & 1.03 & $0.80-1.20$ \\
\hline $\begin{array}{l}\text { Activated Partial } \\
\text { Thromboplastin } \\
\text { Time (APTT) }\end{array}$ & $\begin{array}{l}35.5 \\
\text { seconds }\end{array}$ & 28.6-38.2 seconds \\
\hline Control & $\begin{array}{l}34.0 \\
\text { seconds }\end{array}$ & \\
\hline
\end{tabular}

Table 2: The serum tumour marker values.

\begin{tabular}{|lllll|}
$\begin{array}{l}\text { Serum tumour } \\
\text { marker }\end{array}$ & Reference level & 20.07 .2016 & 22.09 .2016 & 06.10 .2016 \\
CA 125 & $<35.0 \mathrm{U} / \mathrm{ml}$ & $983.10 \mathrm{U} / \mathrm{ml}$ & $84.08 \mathrm{U} / \mathrm{ml}$ & (POD30) \\
AFP & $0.89-8.78 \mathrm{ng} / \mathrm{ml}$ & $1.62 \mathrm{ng} / \mathrm{ml}$ & - & - \\
HCG- BETA & Up to $2.6 \mathrm{mIU} / \mathrm{ml}$ & $0.35 \mathrm{mIU} / \mathrm{ml}$ & - & - \\
\hline
\end{tabular}

Epithelial ovarian tumour marker is raised while germ cell tumour markers are within normal range. 


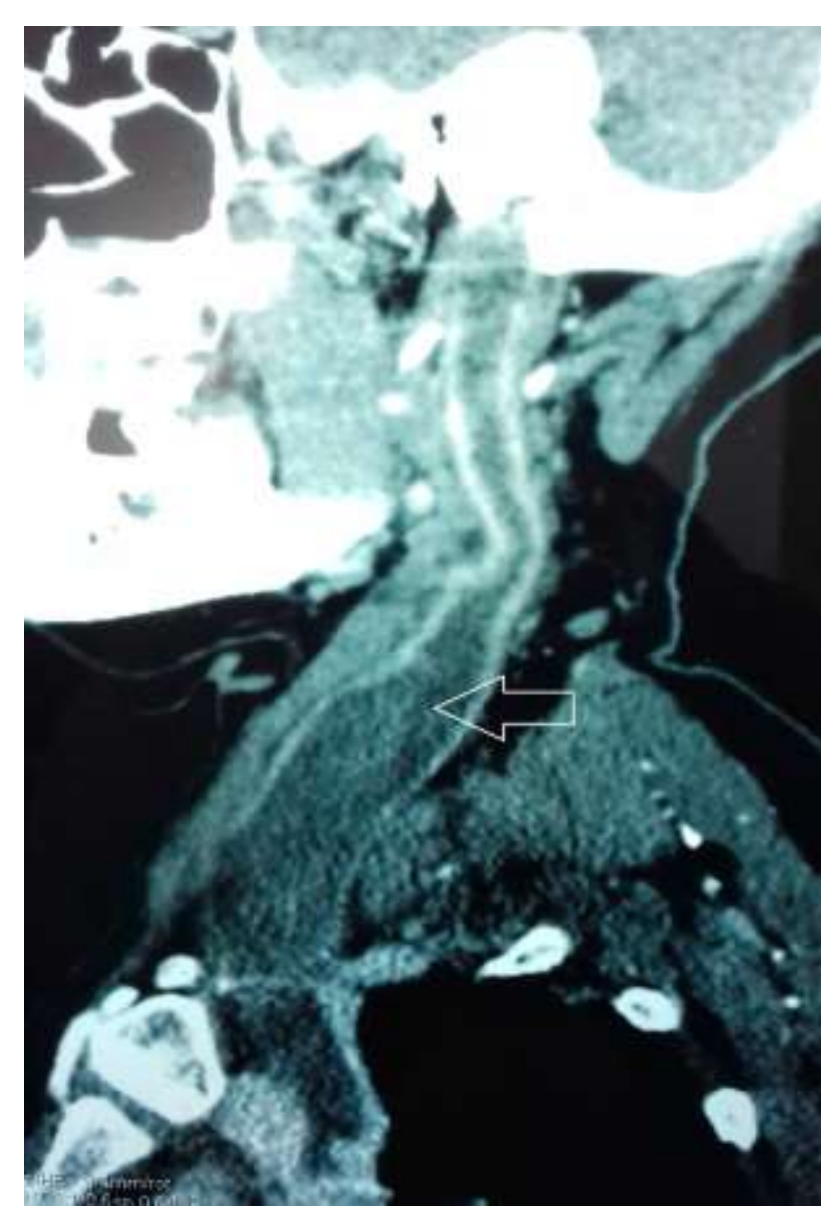

Figure 1: CT scan neck: large thrombus (hypodense) with dilated internal jugular vein with peripheral contrast opacification (arrow mark).

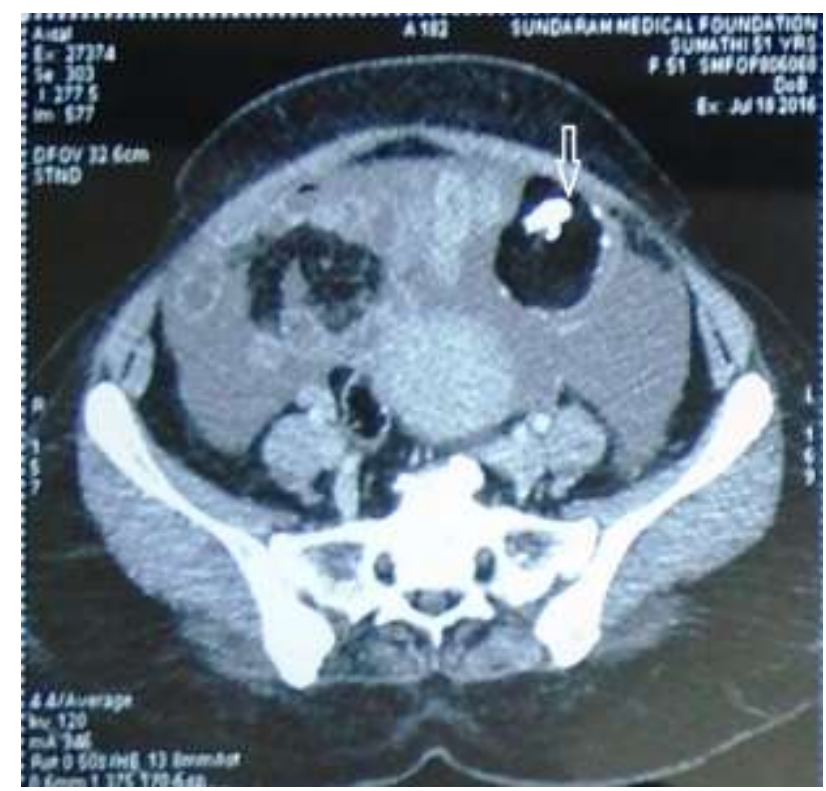

Figure 2: CT scan abdomen: well defined left ovarian mass with fat, calcification, solid and cystic areas (arrow mark).

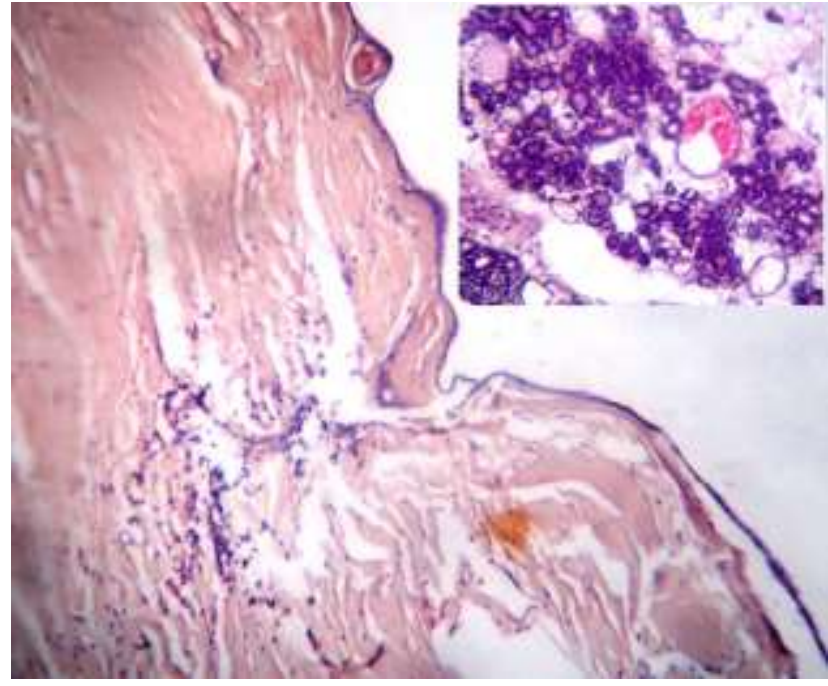

Figure 3: Benign mature cystic teratoma showing skin with adenexa and thyroid parenchyma (insert); $\mathrm{H}$ and E $\times 10$.

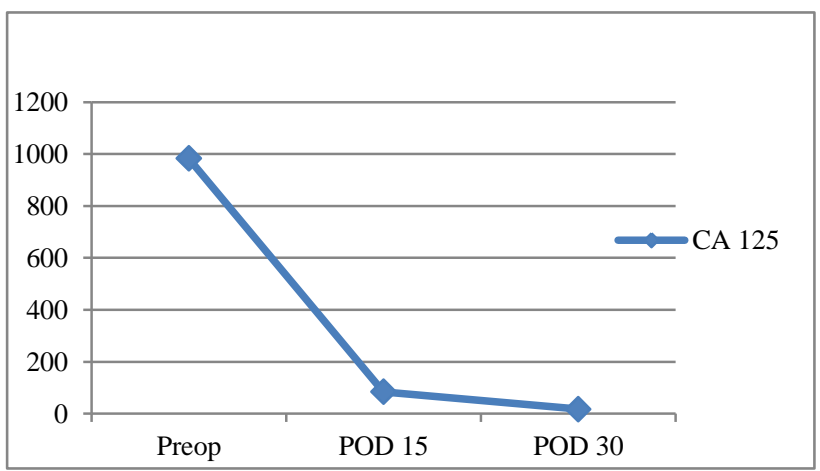

Postoperatively her serum tumour marker CA125 level returned to normal level.

Figure 4: The serum tumour marker CA 125 values.

\section{DISCUSSION}

Spontaneous thrombosis must be considered when there are no obvious predisposing causes of thrombosis. Venous thrombosis may result from a disturbance of normal blood flow with the subsequent activation of coagulation mechanism. The underlying pathophysiology is well understood by Virchow's triad requiring the presence of endothelial damage, alterations of blood flow and/or hypercoagulability of blood to induce thrombosis. Activated clotting factors can gather in areas of sluggish blood flow, and facilitate platelet aggregation leading to thrombosis. Improved ultrasound imaging facilitates the diagnosis of internal jugular vein thrombosis in its earlier course. ${ }^{7}$

Paraneoplastic syndromes are disorders caused by tumour derived products of primary cancer or metastasis which occurs remotely. ${ }^{8}$ It may precede the diagnosis of malignancy. ${ }^{9}$ 
Venous thrombo embolism (VTE) can present as a paraneoplastic phenomenon and may be major causes of morbidity in cancer patients. Appropriate recognition of the syndrome is important because VTE often requires careful medical surveillance and management. ${ }^{9}$

Internal jugular vein thrombosis is a rare vascular disease that can be overlooked or misdiagnosed. ${ }^{10}$ It most commonly occurs in persons with intravenous drug abuse or patients with prolonged central venous catheterization due to iatrogenic trauma. ${ }^{11}$ Other causes are trauma, deep head and neck infections ${ }^{10,11}$ functional neck dissection, hypercoagulability status associated with malignant diseases, and severe ovarian hyperstimulation syndrome. ${ }^{7}$

The most common malignancies associated with thrombosis are pancreatic, lung, stomach and gynaecological malignancies. ${ }^{12}$ Tissue factor (TF) is a trans membrane receptor and primary initiator of blood coagulation. Tumour cells can express TF and spontaneously release high levels of TF-positive microparticles (MPs) into the blood. These highly procoagulant microparticles lead to increased rates of venous thrombosis in cancer patients. ${ }^{13}$

A hypercoagulable state of malignancy occurs due to the activation of coagulation system by tumour cells. Prothrombotic factors in cancer are procoagulants (tissue factor, cancer procoagulant, and factor $\mathrm{V}$ receptor), fibrinolytic substances (plasminogen activator and plasminogen activator inhibitor-1,2) and inflammatory cytokines (IL-1b, TNF-alfa, and VEGF) and the physical interaction between blood (monocytes, platelets, and neutrophils) or vascular cells and tumour cell. ${ }^{14}$

Benign cystic teratoma is an ovarian germ cell tumour arising from primordial germ cells due to failure of meiosis II. Various malignancies can arise from differentiated tissues of these layers. ${ }^{2}$ Because of these features benign cystic teratoma can present with elevation of tumour markers of CA $19-9$ and CA $125 .^{15}$ The most common malignant transformation of is invasive Squamous cell carcinoma, others being Adenocarcinoma, Sarcoma, Carcinoid, Thyroid carcinoma and Melanoma. 16, 17 The correlation between high serum tumour markers and tumour size is due to leakage of cyst contents into bloodstream because of rupture or weakened cyst wall due to larger tumour diameter. ${ }^{18}$ It may also be due to inflammation and tissue necrosis, caused by torsion of benign teratoma. ${ }^{6}$

The CA 125 molecule is expressed in normal peritoneal and fallopian tubes. Inflammation of these tissues can cause elevated serum CA $125 .{ }^{19}$ Paavonen et al studied 33 patients with pelvic inflammatory disease and found increased concentrations of CA 125 values between 100 and 1300 units $/ \mathrm{ml}^{20}$

\section{CONCLUSION}

Benign cystic teratoma of ovary is most common in children and young adults, but rare in peri-menopausal patients. IJV thrombus preceded the diagnosis of benign mature cystic teratoma in this middle-aged patient. Having ruled out other common causes for thrombosis in this age group, it is concluded to be a paraneoplastic presentation of ovarian neoplasm, which preceded the diagnosis of benign cystic teratoma by 4 months. To the best of our knowledge this is the first case report in the literature with an association between internal jugular vein thrombosis and benign cystic teratoma with raised serum tumour marker CA 125.

Funding: No funding sources

Conflict of interest: None declared

Ethical approval: Not required

\section{REFERENCES}

1. Boedeker CC, Ridder GJ, Weerda N. Etiology and therapy of the internal jugular vein thrombosis. Laryngo-Rhino-Otologie. 2004;83(11):743-9.

2. Park CH, Jung MH, Ji YI. Risk factors for malignant transformation of mature cystic teratoma. Obstet Gynecol Sci. 2015;58(6):475-80.

3. Atabekoglu C, Bozaci EA, Tezcan S. Elevated carbohydrate antigen 19-9 in a dermoid cyst. Int J Gynecol Obstet. 2005;91(3):262-3.

4. Madaan M, Puri M, Sharma R, Kaur H, Trivedi SS. Unusually high levels of Ca19-9 associated with mature cystic teratoma of the ovary. Case Rep Obstet Gynecol. 2014;:187910.

5. Dede M, Gungor S, Yenen MC, Alanbay I, Duru NK, Hasimi A. CA19-9 may have clinical significance in mature cystic teratomas of the ovary. Int J Gynecol Cancer. 2006;16(1):189-93.

6. Suh DS, Moon SH, Kim SC, Joo JK, Park WY, Kim KH. Significant simultaneous changes in serum CA19-9 and CA125 due to prolonged torsion of mature cystic teratoma of the ovary. World J Surg Oncol. 2014;12:353.

7. Chlumsky J, Havlin J. Spontaneous jugular vein thrombosis. Acta Cardio. 2009;64(5):689-91.

8. Pelosof LC, Gerber DE. Paraneoplastic syndromes: an approach to diagnosis and treatment. Mayo Clin Proc. 2010;85:838-54.

9. Madabhavi I, Patel A, Choudhary M, Anand A. Paraneoplastic Internal Jugular vein thrombosis leading to diagnosis of bilateral ovarian ependymoma. Case Reports in Obstetrics and Gynaecology. 2014, Article ID 324509. 4 pages.

10. Unsal EE, Karaca C, Ensari S. Spontaneous internal jugular vein thrombosis associated with distant malignancies. Eur Arch Otorhinolaryngol. 2003;260(1):39-41.

11. Chowdhury K, Bloom J, Black MJ, Al-Noury K. Spontaneous and nonspontaneous internal jugular vein thrombosis. Head Neck. 1990;12:168-73. 
12. Edwards RL, Rickels FR. Thrombosis and cancer. Prog Hemost Thromb. 1996;35:374-82.

13. Geddings JE and Mackman N. Tumour-derived tissue factor - positive microparticles and venous thrombosis in cancer patients. Blood. 2013;122(11):1873-80.

14. Caine GJ, Stonelake PS. The hypercoagulable state of malignancy: pathogenesis and current debate. Neoplasia. 2002; 4(6):465-73.

15. Ustunyurt E, Gungor T, Iskender C, Ustunyurt BO, Bilge U, Mollamahmutoglu L. Tumour markers in mature cystic teratomas of the ovary. Arch Gynecol Obstet. 2009;279(2):145-7.

16. Parithivel K, Jagannathan JP, Krajewski K. Ovarian squamous cell carcinoma arising from mature cystic teratoma. Cancer Imaging. 2011;11:67-9.

17. Kudva R, Ayachit GS, Ayachit A. Malignant melanoma arising in an ovarian mature cystic teratoma - a rare entity. J Clin Diagn Res. 2015;9(4):ED14-6.

18. Ulkumen BA, Goker A, Pala HG, Ordu S. Abnormal elevated Ca 19-9 in the dermoid cyst: a sign of the ovarian torsion? Case Rep Obstet Gynecol. 2013;20(13):860.

19. Asher V, Hammond R and Duncan TJ. Pelvic mass associated with raised $\mathrm{Ca} 125$ for benign condition: a case report. World J Surg Oncol. 2010;8:28.

20. Paavonen J, Miettinen A, Heinonen PK, Aaran RK, Teisala K, Aine R et al. Serum CA 125 in acute pelvic inflammatory disease. Br J Obstet Gynecol. 1989;96(5):574-9.

Cite this article as: Vidhya $\mathrm{R}$, Lakshminarasimhan $\mathrm{S}$, Madurai PK. Internal jugular vein thrombosis presenting as paraneoplastic syndrome in benign cystic teratoma of ovary: a case report. Int J Reprod Contracept Obstet Gvnecol 2017:6:287-91. 